\title{
Retraction Note: Frequency of TP53 Mutations and its Impact on Drug Sensitivity in Acute Myeloid Leukemia?
}

\author{
Ankur Shah · Claire Seedhouse
}

Published online: 4 February 2014

(C) Association of Clinical Biochemists of India 2014

Retraction Note: Ind J Clin Biochem (2012)

27(2):121-126

DOI 10.1007/s12291-012-0203-1

This article has been retracted at the request of the second author of the paper, Claire Seedhouse, whose name was included in the paper without her permission. Further, the data in the paper has been published without any approvals from the department or the institution, where the corresponding author, Ankur Shah, was working at the time of submitting this paper.

The online version of the original article can be found under doi:10.1007/s12291-012-0203-1.

\footnotetext{
A. Shah $(\bowtie)$

Department of Molecular Medical Sciences, Queens Medical Centre, University of Nottingham, Nottingham NG7 2UH, UK e-mail: dr.ankurshah82@gmail.com

C. Seedhouse

Department of Academic Haematology, University of

Nottingham, Nottingham, UK
} 